\title{
Clinical Trial Exemption
}

National Cancer Institute

\section{Source}

National Cancer Institute. Clinical Trial Exemption. NCI Thesaurus. Code C142446.

A process that allows sponsors to apply for approval for each clinical study while granting an exemption from the requirement to hold a clinical trial certificate (CTC). 